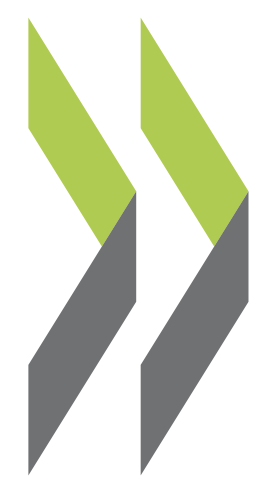

OECD Economics Department Working Papers No. 1057

Thomas Laurent, Fabrice Murtin,

Policy Determinants Geoff Barnard,

of School Outcomes Under Model Uncertainty: Evidence from South Africa

Dean Janse van Rensburg, Vijay Reddy, George Frempong, Lolita Winnaar 
Organisation de Coopération et de Développement Économiques

Organisation for Economic Co-operation and Development

06-Jun-2013

ECONOMICS DEPARTMENT

English - Or. English

POLICY DETERMINANTS OF SCHOOL OUTCOMES UNDER MODEL UNCERTAINTY: EVIDENCE FROM SOUTH AFRICA

ECONOMICS DEPARTMENT WORKING PAPERS No. 1057

By Thomas Laurent, Fabrice Murtin, Geoff Barnard, Dean Janse van Rensburg, Vijay Reddy, George Frempong and Lolita Winnaar

All Economics Department Working Papers are available through OECD's Internet website at http://www.oecd.org/eco/Workingpapers

JT03341108

Complete document available on OLIS in its original format

This document and any map included herein are without prejudice to the status of or sovereignty over any territory, to the delimitation of international frontiers and boundaries and to the name of any territory, city or area. 


\section{ABSTRACT/RÉSUMÉ \\ Policy determinants of school outcomes under model uncertainty: evidence from South Africa}

In this paper we assess the determinants of secondary school outcomes in South Africa. We use Bayesian Averaging Model techniques to account for uncertainty in the set of underlying factors that are chosen among a very large pool of explanatory variables in order to minimize the risk of omitted variable bias. Our analysis indicates that the socioeconomic background of pupils, demographic characteristics such as population groups (Black and White) as well as geographical locations account for a significant variation in pupils' achievement levels. We also find that the most robust policy determinants of pupils' test scores are the availability of a library at school, the use of IT in the classroom as well as school climate.

This Working Paper relates to the 2013 OECD Economic Survey of South Africa (http://www.oecd.org/eco/surveys/southafrica2013.htm).

JEL codes: $\mathrm{I} 2, \mathrm{H} 4, \mathrm{C} 2, \mathrm{O} 2$.

Keywords: Education; South Africa; Bayesian Averaging Model

Les politiques d'éducation face à l'incertitude de la modélisation : l'Afrique du Sud à l'étude

Cette étude estime les déterminants des résultats scolaires en Afrique du Sud. Des techniques Bayésiennes de sélection de modèle sont utilisées pour traiter l'incertitude dans le choix des variables explicatives, lesquelles sont tirées d'un ensemble très large de variables candidates aidant à minimiser le biais d'omission. Les résultats indiquent que le profil socio-économique des élèves, les caractéristiques démographiques telles que l'appartenance ethnique ou la localisation géographique expliquent une partie importante des différences de performance scolaire entre élèves. Les politiques éducatives corrélées aux résultats scolaires sont la disponibilité de bibliothèques à l'école, l'utilisation des technologies de l'information en classe ainsi que la discipline à l'école.

Ce Document de travail se rapporte à l'Étude économique de l'Afrique $d u$ Sud, 2013, (http://www.oecd.org/fr/eco/etudes/afriquedusud2013.htm).

Codes JEL: I2, H4, C2, O2.

Mots-clés: Éducation; Afrique du Sud ; Choix de modèle Bayésien

C) OECD (2013)

You can copy, download or print OECD content for your own use, and you can include excerpts from OECD publications, databases and multimedia products in your own documents, presentations, blogs, websites and teaching materials, provided that suitable acknowledgment of OECD as source and copyright owner is given. All requests for commercial use and translation rights should be submitted to rights@oecd.org 


\section{TABLE OF CONTENTS}

\section{POLICY DETERMINANTS OF SCHOOL OUTCOMES UNDER MODEL UNCERTAINTY:}

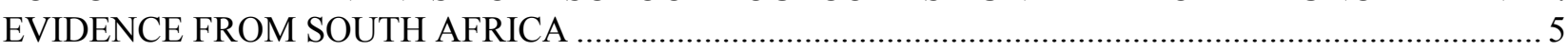

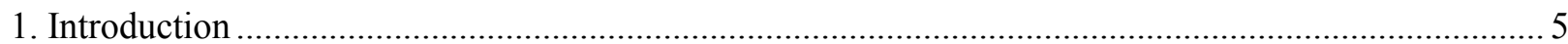

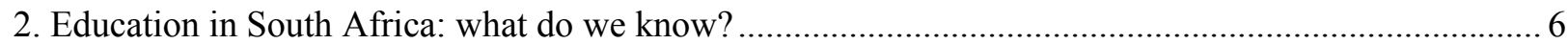

2.1. Systemic Inequity, Bimodal Outcomes and Input-Based Education ........................................... 6

2.2. Contextual and Policy Determinants of Educational Outcomes ..................................................... 7

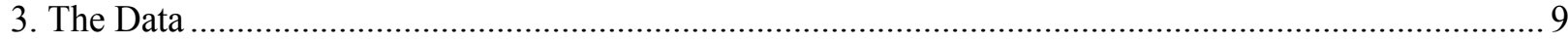

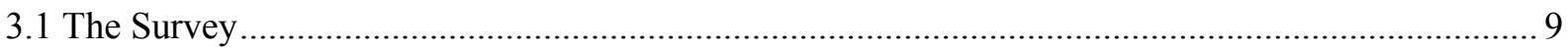

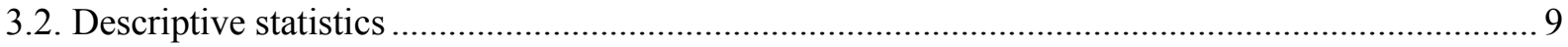

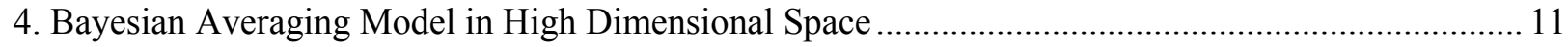

5. The Determinants of Secondary School Outcomes in South Africa ............................................... 15

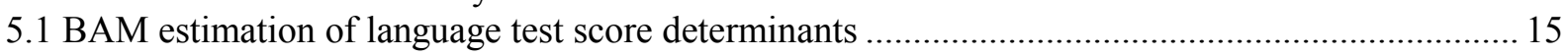

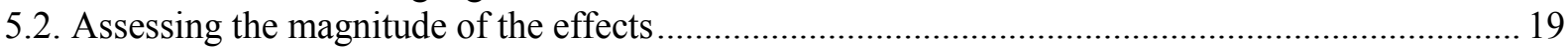

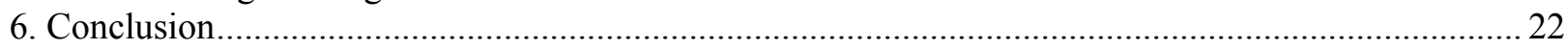

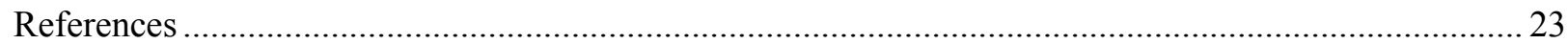

\section{Tables}

1. Socio-economic Determinants of Educational Outcomes in South Africa ......................................... 7

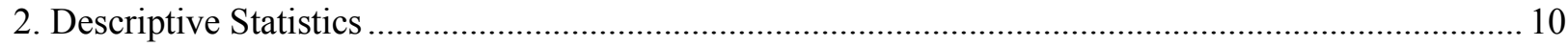

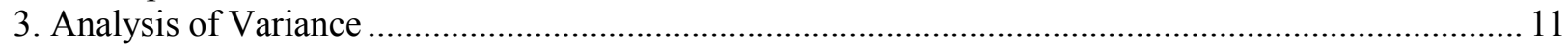

4. Bayesian Averaging Model Estimation of Language Test Scores ................................................. 16

5. Relative Impact of Covariates on Square Root of Test Scores........................................................... 20

\section{Figures}

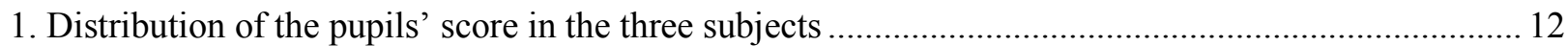

2. Distribution of the square root of the pupils' score in language ....................................................... 13 
ECO/WKP(2013)49 
ECO/WKP(2013)49

\title{
POLICY DETERMINANTS OF SCHOOL OUTCOMES UNDER MODEL UNCERTAINTY: EVIDENCE FROM SOUTH AFRICA
}

\author{
By Thomas Laurent, Fabrice Murtin, Geoff Barnard, Dean Janse van Rensburg, Vijay Reddy, \\ George Frempong and Lolita Winnaar ${ }^{1}$
}

\section{Introduction}

A large number of studies have analysed the economic determinants of school outcomes both at the individual country level and across countries (see Hanushek and Woessmann, 2010, for a survey). At the country level, these studies typically focus on a wide set of factors, ranging from family socio-economic background to teacher, class and school-level characteristics. At the aggregate cross-country level, the correlation between average country scores in international surveys such as the Programme for International Student Assessment (PISA), Trends in International Mathematics and Science Study (TIMSS) or Progress in International Reading Literacy Study (PIRLS), and the total amount of financial resources injected into the education system is often found to be weak among high-income countries (e.g. OECD, 2012), suggesting that a wide range of factors other than total physical resources may matter in reality.

In practice, assessing the determinants of school outcomes, as measured by pupils' test scores, is made difficult by the number of potential explanatory variables. Limiting the set of potential determinants exposes the analysis to omitted variable bias, while increasing it in an excessive manner may raise multicolinearity problems and blur coefficients' estimates. To cope with this empirical trade-off and gauge the robustness of the results, it is desirable to test for the sensitivity of classical estimates to the set of control variables, especially in high-dimensional contexts where the number of potential determinants is large. To that aim, Bayesian Averaging Model (henceforth BAM) techniques allow to calculate the average estimate of a given variable across a multitude of empirical models, thereby allowing for model's uncertainty.

In this paper, we run a BAM analysis of test scores conducted in South African secondary schools in 2009. We consider a very large number of potential determinants (about one hundred) to minimize the risk of omitted variable bias. The set of explanatory variables includes learner characteristics (race, family wealth and socio-economic background, language spoken at home), school characteristics (physical and human resources, school climate, school principal characteristics), teachers characteristics and teaching policy (teaching intensity, assessment policy) as well as geographical controls. The BAM algorithm allows us to select the set of variables that are the most robustly associated with test scores among a high number of potential candidate variables. Doing so, we aim to disentangle policy and contextual variables. In practice, policy-makers are primarily interested in policy effects, which receive most of our attention.

1. Laurent: Institut National de la Statistique et des Études Économiques (France), thomas.laurent@,insee.fr; Murtin: OECD (Statistics Directorate), fabrice.murtin@oecd.org; Barnard: OECD (Economics Department), geoff.barnard@oecd.org; Janse van Rensburg: Human Sciences Research Council (HSRC, South Africa), djansevanrensburg@hsrc.ac.za ; Reddy: Human Sciences Research Council, vreddy@hsrc.ac.za; Frempong: Human Sciences Research Council, gfrempong@hsrc.ac.za; Winnaar: Human Sciences Research Council, lwinnaar@hsrc.ac.za. The authors are grateful for invaluable comments received from Andrew Dean, Balàsz Egert, Bob Ford, Andreas Wörgötter, and other colleagues from the OECD and HSRC. The views expressed in this paper are those of the authors, and not necessarily those of the OECD or its member countries, or those of the Human Sciences Research Council. Josiane Gutierrez and Mikel Iñarritu are acknowledged for secretarial assistance. 
As a result, we find a large correlation between test scores and socio-economic status in postapartheid South Africa, with first language, wealth and place of residence all being strong determinants of school outcomes. As a main contribution to the economic policy literature on the subject, we show that learning materials, in the form of library availability and IT use in the classroom, as well as school climate, and class repetition are the most robust policy factors positively associated with test scores. While the absence of any instrumentation technique prevent us from making any causal assessment, this finding paves the way for further research on the causal effect of school equipment on school outcomes in South Africa.

Section 2 presents a brief review of the literature on the determinants of education quality, and the specific challenges faced by South Africa. Section 3 introduces the data set and describes data construction. Section 4 presents the BAM methodology. Section 5 presents the results, while last section concludes.

\section{Education in South Africa: what do we know?}

Understanding the causes of variation in educational outcomes in South Africa has improved significantly in recent years, as increasing data availability has allowed the application of more sophisticated statistical techniques. In particular, data from Education Management Information Systems (EMIS), surveys (General Household Survey, National Income Dynamics Survey, Cape Area Panel Study), international benchmarking studies (PIRLS and TIMSS) as well as national test data (Grade 12 result data, Systemic Evaluations, Annual National Assessments) have been useful for investigating the education production function in South Africa ${ }^{2}$. Studies utilising these data typically document the inequity inherent to the system and the consistently low performance of South African learners. This section intends to provide a synthesis of literature related to the drivers of educational outcomes in South Africa.

\subsection{Systemic Inequity, Bimodal Outcomes and Input-Based Education}

South African society remains divided along socio-economic lines. The education system in South Africa mirrors and perpetuates this societal phenomenon, as youth from less affluent backgrounds are more likely to attend historically disadvantaged schools and exhibit lower educational outcomes. Despite increased public investment in education and a rebalancing of public funding towards schools in disadvantaged areas, the dispersion of school resources remains very wide, with historically advantaged schools continuing to enjoy much higher total funding per pupil and greater availability of infrastructure, books, IT...This divide originates from historically unequal resourcing - both in terms of funding, physical capital and human capital (Fleisch, 2008; Lam, et al, 2008; Reddy 2003, Reddy, et al, 2012; Taylor, et al, 2011; Van der Berg, 2007).

During the Apartheid era school choice for Black, White, Indian and Coloured children (and families) was restricted by race and geographical location. There were education departments for each of the ethnic group, but funding was determined centrally. Case and Deaton (1999) investigated determinants of literacy and numeracy scores, using school and household data collected just prior to the end of apartheid. Case and Deaton found that high learner/educator ratios were associated with poor performance and attainment. Similarly Black learners experienced high marginal returns to increased home resources, indicating that

2. Gustafsson and Mabogoane (2010) note the difficulties of estimating an education production function, in particular that no single such function can be determined definitively. The emergence of dedicated education performance and learner background data and more developed modelling techniques, however, address some of these concerns. In particular, international benchmarking studies make available data that were previously inaccessible. 
educational outcomes are constrained in disadvantaged households. Case and Yogo (1999), Van der Berg and Burger (2003) as well as Fedderke and Luiz (2002) echoed these findings. The latter confirm that school inputs influence educational outcomes in resource-scarce environments, and furthermore show that even in well-resourced White communities school inputs play a role.

\subsection{Contextual and Policy Determinants of Educational Outcomes}

Table 1 describes the determinants commonly used in economic studies that estimate the education production function either at the school or individual level in South Africa. These are typically grouped into contextual variables (parental and individual factors) and policy determinants in a broad sense, which include school and teacher-level variables upon which the South African government can have some influence. Home and individual characteristics of learners typically relate to the socioeconomic context in which the child lives or has grown up in, as well as exposure to a learning-conducive home environment.

Table 1. Socio-economic Determinants of Educational Outcomes in South Africa

\begin{tabular}{|c|c|}
\hline Determinant & Relative Effect \\
\hline \multicolumn{2}{|l|}{ Contextual Determinants } \\
\hline $\begin{array}{l}\text { Age } \\
\text { When the age of a learner is higher or lower than expected, learners perform below } \\
\text { their peers }\end{array}$ & $\begin{array}{l}\text { Negative as age } \\
\text { diverges from } \\
\text { expected age }\end{array}$ \\
\hline $\begin{array}{l}\text { Parental wealth } \\
\text { A register of household assets can be used to create a proxy for SES. Certain assets } \\
\text { also act to create a learning-conducive home environment }\end{array}$ & $\begin{array}{c}\text { Positive as } \\
\text { normal assets } \\
\text { increase }\end{array}$ \\
\hline $\begin{array}{l}\text { Gender } \\
\text { The gender gap in performance indicates the relative efficiency of male to female } \\
\text { learners, and their responses to educational inputs }\end{array}$ & Contextual \\
\hline $\begin{array}{l}\text { Home and school language convergence } \\
\text { Learners who speak the language of instruction more fluently perform better. Thus } \\
\text { learners who do not speak the language of instruction at home perform lower }\end{array}$ & $\begin{array}{l}\text { Same Positive } \\
\text { Different } \\
\text { Negative }\end{array}$ \\
\hline $\begin{array}{l}\text { Parental education } \\
\text { Learners tend to perform better in households where parents' educational } \\
\text { attainment is higher }\end{array}$ & $\begin{array}{l}\text { Positive as } \\
\text { parental } \\
\text { attainment rises }\end{array}$ \\
\hline $\begin{array}{l}\text { Race } \\
\text { Race, in post-Apartheid South Africa, can differentiate a longer-term history of } \\
\text { affluence and relative advantage }\end{array}$ & $\begin{array}{c}\text { Positive } \\
\text { (on affluence) }\end{array}$ \\
\hline $\begin{array}{l}\text { Urban location } \\
\text { Learners living in an urban setting typically outperform learners living in rural } \\
\text { areas. Urban-based learners typically enjoy higher household incomes and } \\
\text { access to infrastructure, as well as other SES related advantages. The extent } \\
\text { to which a learner is within a rural or urban location will also have bearing on } \\
\text { the school attended. Rural schools face similar challenges as those listed } \\
\text { here, especially in that they serve less affluent communities and have less } \\
\text { access to government services }\end{array}$ & $\begin{array}{l}\text { Urban Positive } \\
\text { Rural Negative }\end{array}$ \\
\hline \multicolumn{2}{|l|}{ Policy Determinants } \\
\hline $\begin{array}{l}\text { School equipment } \\
\text { These include various types and numbers of classrooms and equipment }\end{array}$ & $\begin{array}{c}\text { Positive as } \\
\text { normal assets }\end{array}$ \\
\hline
\end{tabular}




\begin{tabular}{|c|c|}
\hline $\begin{array}{l}\text { available, such as computer labs, libraries, science labs and sports facilities; } \\
\text { assets to facilitate learning such as chalkboards, textbooks, desks, chairs, } \\
\text { projectors, copiers and computers; and infrastructure such as administrative } \\
\text { offices (principal's office), telecommunications, piped water and electricity, } \\
\text { as well as a measure of a safe environment. Controls associated with better } \\
\text { infrastructure trend to return positive marginal influences on performance, } \\
\text { while indicators for crime or inferior infrastructure and assets to be negative }\end{array}$ & $\begin{array}{l}\text { and } \\
\text { infrastructure } \\
\text { improves }\end{array}$ \\
\hline $\begin{array}{l}\text { Ex-department } \\
\text { The Apartheid dispensation classified schools in terms of racial departments. } \\
\text { This system included multiple education departments separated by race and } \\
\text { location (i.e. homeland and province), grouped into the four largest race } \\
\text { groups in South Africa at the time; Black, Coloured, Indian and White. These } \\
\text { departments differed in terms of funding as well as curriculum. }\end{array}$ & $\begin{array}{l}\text { White }++ \\
\text { Indian }+ \\
\text { Coloured } \pm \\
\text { Black - }\end{array}$ \\
\hline $\begin{array}{l}\text { Learner-educator ratio } \\
\text { As learner to educator ratio rises less individual attention can be given to } \\
\text { each learner, thus an inverse relationship is expected. A similar indicator is } \\
\text { that of "class size", essentially a learner to class ratio. }\end{array}$ & Negative \\
\hline $\begin{array}{l}\text { School Quintile (relative ranking of schools by resources) } \\
\text { Schools in South Africa are divided administratively into community and } \\
\text { school resource based quintiles. The quintile system is the mechanism by } \\
\text { which the state administers stepped funding, whereby the lowest quintiles } \\
\text { receive the highest per-learner subsidy and are designated no-fee school } \\
\text { status. Evidence suggests there is low differentiation among the lower three } \\
\text { quintiles, with quintile five schools performing best in the system. These } \\
\text { quintiles are regarded as being poorly determined }\end{array}$ & $\begin{array}{l}\text { Positive as } \\
\text { quintile rises }\end{array}$ \\
\hline $\begin{array}{l}\text { Educator related } \\
\text { These variables refer to the characteristics of the teachers in schools, } \\
\text { personal and professional, especially teaching qualifications held. A positive } \\
\text { relationship reappears throughout the literature. }\end{array}$ & $\begin{array}{l}\text { Positive as } \\
\text { educator } \\
\text { qualifications } \\
\text { increase }\end{array}$ \\
\hline $\begin{array}{l}\text { User fees charged } \\
\text { The presence of (higher) fees indicates better resources in the school as well } \\
\text { as in the community which that school serves. }\end{array}$ & Positive \\
\hline
\end{tabular}

Note: assessment based on Fedderke and Luiz, 2002; Fiske and Ladd, 2003; Lee et al, 2005; Moloi, and Strauss, 2005; Oosthuizen and Bhorat, 2006; Gustafsson,2007; Louw et al, 2007; Van der Berg, 2007; Bhorat and Oosthuizen, 2008; Fleisch, 2008; Lam et al, 2008; Van der Berg, 2008; Armstrong, 2009; Chudgar and Kanjee, 2009; Taylor and Yu, 2009; Van der Berg, 2009; Ardington et al, 2011; Frempong et al, 2011; Taylor et al, 2011. 
ECO/WKP(2013)49

\section{The Data}

\subsection{The Survey}

The data set is built on seven questionnaires from the 2009 Systemic Studies conducted at grade 9 by the South African Human Sciences Research Council. Pupils answer to three questionnaires that correspond to the language, mathematics and natural science tests respectively, teachers answer three other subject-specific questionnaires and the last one is completed by the school principal. There are three dependant variables, corresponding to the test scores in language (English or Afrikaans), mathematics and science. The tests are administered in English or in Afrikaans.

The treatment of the seven questionnaires involved the creation of a large number of indicators spanning a wide range of issues. In many cases, questions dealing with a similar issue were grouped and a principal component analysis was applied to construct a more informative set of variables. For instance, parental socio-economic status is obtained as the first component from a principal component analysis run on household size, orphan dummy, education of father and mother, reading frequency at home, books availability at home, dummies for household having electricity and a list of dwelling equipments and meal frequency of the learner. Details on the construction of each indicator are included in a companion paper available upon request.

Moreover, some missing data were imputed in order to maximize the size of the sample. Given that a large number of explanatory variables are considered, avoiding data imputation would dramatically lower the sample size and raise the risk of obtaining a selected sample as questionnaires are more likely to be entirely filled in well-performing schools. In absence of any strong prior on the values of missing data, we imputed them at random by drawing from the empirical distribution of observed variables. In some cases, we had stronger priors on the value of missing data and chose the imputed figure. For instance, the share of parents who do not pay school fees happened to be underestimated in the sample with respect to national average (63\% versus $69 \%$ at national level). When the missing observations of the dummy 'parents pay school fees' are replaced by zero, the share of parents paying school fees jumps to $68 \%$. In any case, we have minimized the influence of imputation by including variables that count the number of imputed missing values for each learner in various sections of the questionnaire.

As a result, we use 98 explanatory variables, which are classified in three categories: 32 variables reflect contextual effects such as geographical location, pupils characteristics (gender, mother tongue, ethnic group, parental wealth) and school characteristics (socio-economic and historical background); 49 variables are deemed to carry some policy effects such as school equipment or human resources, school climate (capturing student discipline problems as well as absenteeism), school principal and teacher characteristics and teaching policies (time table, assessment and curriculum policies); 17 variables count the number of missing values that have been imputed for each pupils in various areas of the questionnaire.

\subsection{Descriptive statistics}

For statistical reasons that will become clear in the next section, our dependent variables are the square roots of pupils' test scores. Table 2 presents some descriptive statistics (mean, standard deviation and coefficient of variation) of the dependent variables for different groups.

Test score differences between Africans and Coloured on one side and Whites and Indians on the other are large and are comprised between one and two standard deviations for the three subjects. Not surprisingly, as ethnicity and first language are linked, similar differences are observed between English and Afrikaans on one side and pupils speaking an African language as mother tongue on the other. There is also a strong geographical divides, with urban dwellings and inhabitants of Gauteng, Western Cape and Northern Cape displaying better outcomes. 
Table 2. Descriptive Statistics

\begin{tabular}{|c|c|c|c|c|c|c|c|c|c|}
\hline & \multicolumn{3}{|c|}{ Language } & \multicolumn{3}{|c|}{ Maths } & \multicolumn{3}{|c|}{ Science } \\
\hline & Mean & SD & CV (in \%) & Mean & SD & CV (in \%) & Mean & SD & CV (in \%) \\
\hline Total population & 21,96 & 11,93 & 54,4 & 10,26 & 5,54 & 53,9 & 12,15 & 5,59 & 46,0 \\
\hline \multicolumn{10}{|c|}{ By population group } \\
\hline African & 20,01 & 10,84 & 54,2 & 9,28 & 4,42 & 47,6 & 11,21 & 4,74 & 42,3 \\
\hline Coloured & 27,59 & 10,92 & 39,6 & 11,75 & 5,00 & 42,5 & 14,03 & 5,14 & 36,7 \\
\hline Indian & 34,62 & 19,58 & 56,6 & 15,67 & 8,95 & 57,1 & 17,05 & 8,19 & 48,1 \\
\hline White & 36,98 & 13,33 & 36,0 & 20,38 & 8,53 & 41,9 & 21,67 & 7,56 & 34,9 \\
\hline \multicolumn{10}{|c|}{ By native language } \\
\hline African language & 19,86 & 10,80 & 54,4 & 9,22 & 4,39 & 47,6 & 11,16 & 4,72 & 42,3 \\
\hline Afrikaan & 30,63 & 11,95 & 39,0 & 14,49 & 7,39 & 51,0 & 16,49 & 6,81 & 41,3 \\
\hline English & 33,61 & 15,09 & 44,9 & 14,98 & 7,38 & 49,3 & 16,63 & 7,23 & 43,5 \\
\hline \multicolumn{10}{|l|}{ By gender } \\
\hline Female & 23,81 & 12,34 & 51,8 & 10,39 & 5,59 & 53,8 & 12,30 & 5,61 & 45,6 \\
\hline Male & 20,11 & 11,22 & 55,8 & 10,13 & 5,48 & 54,0 & 12,00 & 5,56 & 46,3 \\
\hline \multicolumn{10}{|l|}{ By location } \\
\hline Urban & 33,26 & 13,36 & 40,2 & 16,30 & 8,25 & 50,6 & 18,10 & 7,60 & 42,0 \\
\hline Township & 23,85 & 10,95 & 45,9 & 10,39 & 4,85 & 46,6 & 12,52 & 4,95 & 39,6 \\
\hline Rural & 19,84 & 11,13 & 56,1 & 9,33 & 4,69 & 50,2 & 11,22 & 4,94 & 44,1 \\
\hline \multicolumn{10}{|l|}{ By Province } \\
\hline Eastern Cape & 17,76 & 10,77 & 60,6 & 8,65 & 4,34 & 50,2 & 10,16 & 4,37 & 43,1 \\
\hline Free State & 25,15 & 11,66 & 46,4 & 11,41 & 5,60 & 49,0 & 13,36 & 5,91 & 44,3 \\
\hline Gauteng & 27,27 & 11,82 & 43,3 & 12,22 & 6,81 & 55,8 & 15,18 & 6,37 & 42,0 \\
\hline KwaZulu Natal & 18,66 & 11,69 & 62,7 & 9,36 & 5,43 & 58,0 & 10,55 & 5,05 & 47,9 \\
\hline Limpopo & 17,57 & 10,21 & 58,1 & 8,58 & 4,44 & 51,7 & 10,42 & 4,69 & 45,0 \\
\hline Mpumalanga & 24,01 & 11,53 & 48,0 & 10,58 & 5,70 & 53,9 & 13,14 & 5,79 & 44,1 \\
\hline North Cape & 26,89 & 11,05 & 41,1 & 12,40 & 5,81 & 46,9 & 14,98 & 5,92 & 39,6 \\
\hline North West & 21,79 & 10,79 & 49,5 & 9,55 & 4,19 & 43,9 & 12,23 & 4,92 & 40,2 \\
\hline Western Cape & 28,35 & 11,72 & 41,3 & 12,80 & 6,07 & 47,4 & 13,72 & 5,37 & 39,1 \\
\hline
\end{tabular}

Table 3 presents a variance analysis of test scores according to different grouping. It further illustrates the importance of ethnic and socio-economic factors in education outcomes. The latter analysis displays, for each grouping, three statistics: The share of test scores' variance explained by the grouping variable, the standard deviation of the between groups' effect (i.e. by how much groups differs in terms of test score), and the standard deviation of the within-group effect (i.e. by how much people in the same group differs in terms of test score).

As a result, about one fifth of test scores' variance is accounted for by ethnicity or (parental/school) socio-economic status (SES). Notice that in OECD countries, the share of variance in PISA test scores explained by parental socio-economic status is significantly lower and equal to $13 \%$ (OECD, 2009). Other variables with high explanatory power are first language and school location (whether the school is in an urban, suburban or rural area). All variables mentioned above display a between-group effect at least greater than half the standard deviation of the test score. Obviously, all of the latter dimensions are particularly inter-twined in South Africa. 
ECO/WKP(2013)49

Table 3. Analysis of Variance

By population group

By native language

By gender

By location

By Province

By School quintile

By population group

By native language

By gender

By location

By Province

By School quintile

By population group

By native language

By gender

By location

By Province

By School quintile

\section{Language}

\begin{tabular}{ccc} 
R Squared & SD of group effect & SD within group \\
\hline 0,14 & 5,19 & 11,06
\end{tabular}

$0,13 \quad 5,34 \quad 11,11$

$0,02 \quad 2,61 \quad 11,79$

$0,10 \quad 4,71 \quad 11,30$

$0,12 \quad 4,34 \quad 11,21$

$\begin{array}{lll}0,16 & 5,38 & 10,92\end{array}$

Maths

\begin{tabular}{ccc} 
R Squared & SD of group effect & SD within group \\
\hline 0,23 & 3,07 & 4,85
\end{tabular}

$0,15 \quad 2,59 \quad 5,12$

$0,00 \quad 0,16 \quad 5,53$

$0,13 \quad 2,44 \quad 5,16$

$0,08 \quad 1,65 \quad 5,31$

$\begin{array}{lll}0,18 & 2,59 & 5,03\end{array}$

Science

\begin{tabular}{ccc} 
R Squared & SD of group effect & SD within group \\
\hline 0,20 & 2,86 & 5,01
\end{tabular}

$0,14 \quad 2,55 \quad 5,18$

$0,00 \quad 0,19 \quad 5,59$

$0,12 \quad 2,38 \quad 5,24$

$\begin{array}{lll}0,11 & 1,97 & 5,27\end{array}$

$0,18 \quad 2,65 \quad 5,06$

\section{Bayesian Averaging Model in High Dimensional Space}

In this section, we present the Bayesian framework used to select the set of most robust explanatory variables among a very large number of candidates. Test scores are the joint outcome of contextual variables (e.g. parental SES and school SES) and school environment, which is influenced to some extent by policy and institutional reforms. However, determining the exact nature of the effects at stake is made difficult by the high number of contextual and policy variables observed in the data. One common approach is to start with the full set of candidate variables, which is here very large, and to suppress nonsignificant terms, but this process is neither very robust nor efficient as it does not guarantee that another subset of covariates give a better explanation of the studied phenomenon (here, school outcome), as noted in Hoeting and al. (1999).

To solve this statistical problem, a Bayesian Model Averaging (BMA) approach is proposed to determine the set of factors that significantly affect test scores. We use the Bayesian Averaging Model toolbox for Matlab/R (Zeugner, 2011), which is standard and can be downloaded from http://bms.zeugner.eu/matlab/ together with tutorials. The idea is to start with some prior on which model is the most likely (it could be, without specific knowledge on the model, to attribute equal probabilities to each model or to the inclusion of each variable) and to estimate a posterior model probability applying Bayes' rule. Intuitively, the posterior model probability is the combination of the model's prior and the likelihood of the model, which carries all the information contained in the data. 
Formally, let $\mathrm{X}$ denote the set of all possible explanatory variables. The goal of this study is to find a subset $X_{\gamma} \in X$ that significantly affects the scores, i.e. to find the "best" relationship of the following form:

$$
y=\alpha_{\gamma}+\beta_{\gamma} X_{\gamma}+\varepsilon \quad \varepsilon \sim N\left(0, \sigma^{2} I\right)
$$

with y being the test score, $\alpha_{\gamma}$ a constant, $\beta_{\gamma}$ the coefficients and $\varepsilon$ a normally distributed error term of variance $\sigma^{2}$.

As shown on Figure 1, the statistical distributions of test scores display much skewness (large deviations on the right tail) and they are not normally distributed. As the Gaussian assumption is a crucial assumption of our framework, we transform the data by taking the squared root of each score. For all test scores, this data transformation yields distributions much closer to normality (see Figure 2).

Then, if $M_{\gamma}$ denotes the model with regressors $X_{\gamma}$, the posterior model probability (PMP) attached to $M_{\gamma}$ is by Bayes' rule:

$$
P M P_{\gamma}=p\left(M_{\gamma} \mid y, X\right)=\frac{p\left(y \mid M_{\gamma}, X\right) p\left(M_{\gamma}\right)}{p(y \mid X)}
$$

Figure 1. Distribution of the pupils' score in the three subjects

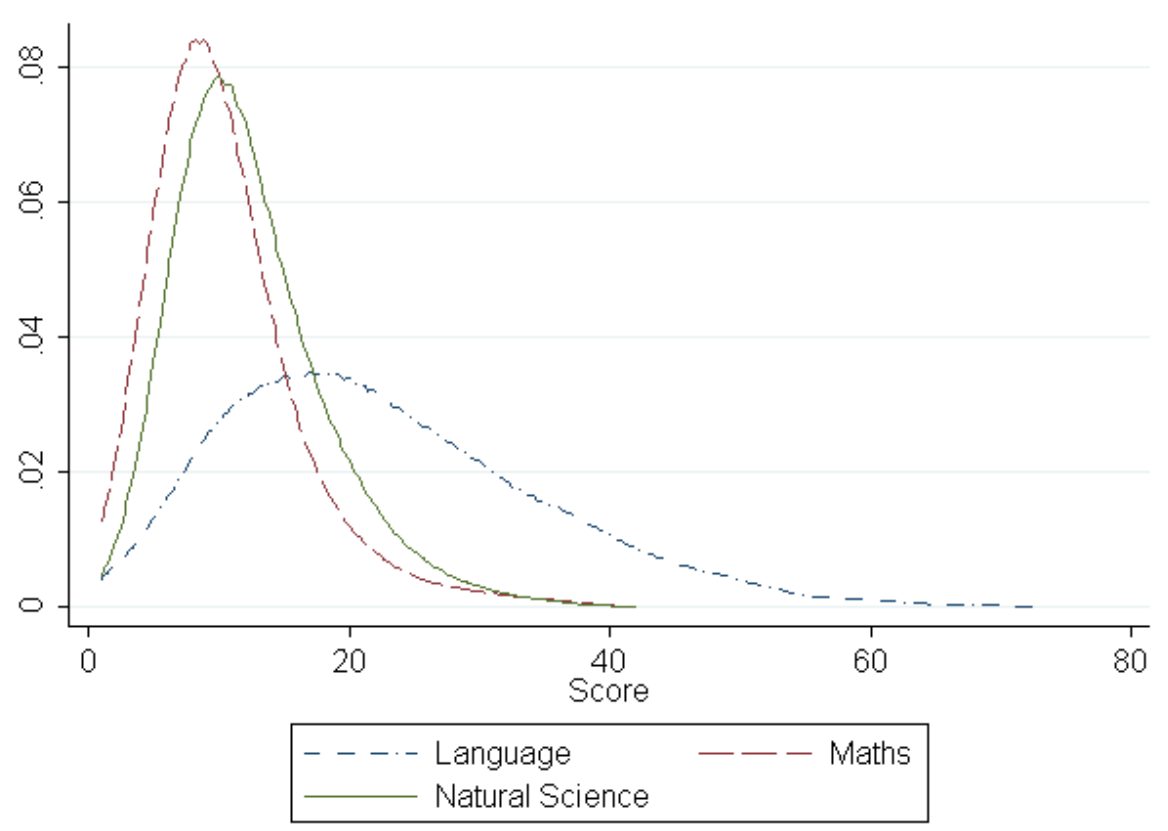


Figure 2. Distribution of the square root of the pupils' score in language

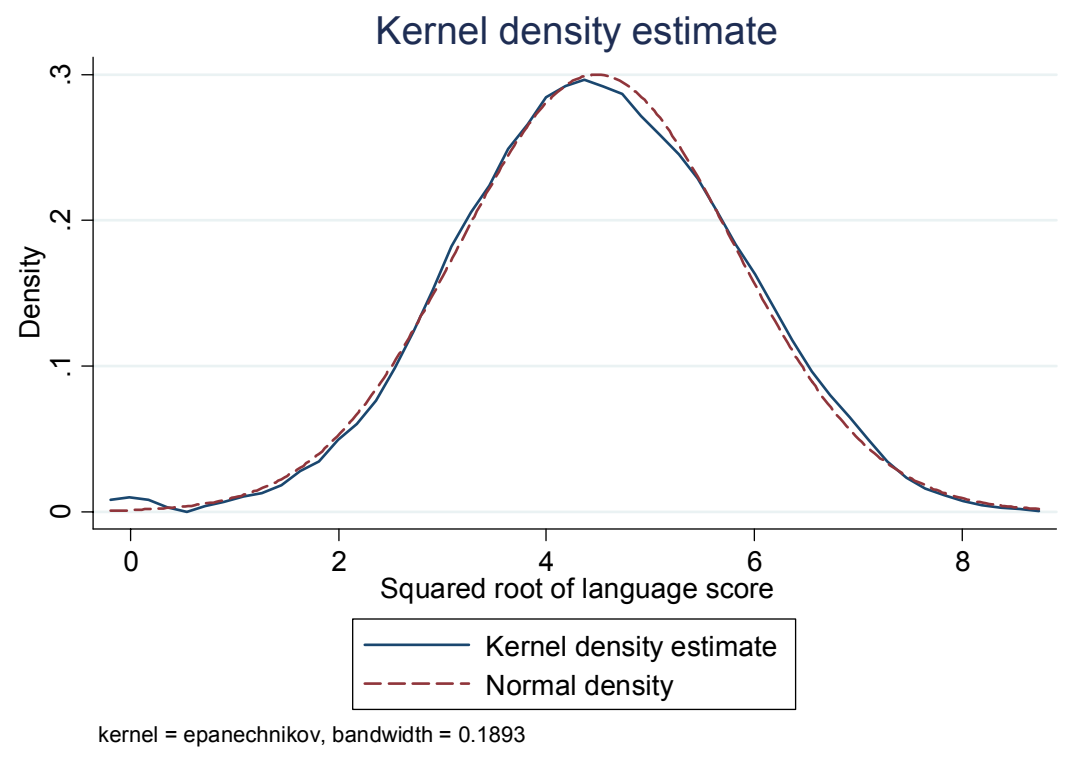

As $p(y \mid X)$ is independent of the model considered, the PMP is proportional to the model prior $p\left(M_{\gamma}\right)$ times the marginal likelihood of the data given the model $p\left(y \mid M_{\gamma}, X\right)$. The idea of BMA is then to use these PMPs as weights to infer average posterior distribution of the coefficients:

$$
p(\beta \mid y, X)=\sum_{\gamma} P M P_{\gamma} \cdot p\left(\beta \mid y, X, M_{\gamma}\right)
$$

We use classical Bayesian linear regression for the estimation of marginal likelihoods $p\left(y \mid M_{\gamma}, X\right)$ and posterior distributions $p\left(\beta \mid y, X, M_{\gamma}\right)$ inside each model (see below). We adopt then a two-step Bayesian framework, while estimating in a first step a probabilistic distribution on the choice of the model, and in a second step a probabilistic distribution on the parameters of the model. The choice of priors in each of these two steps is discussed below.

\section{Choice of priors}

There are two main alternatives for model's prior, namely attributing the same probability to each possible model, or the same probability to the inclusion of each possible variable.

Let us consider the first case. With K possible variables, there are $2^{K}$ possible models. Hence each of them receives a identical prior probability $p\left(M_{\gamma}\right)=2^{-K}$. The prior expected model size (i.e. the number of included explanatory variables) is $\sum_{k}\left(\begin{array}{l}K \\ k\end{array}\right) k 2^{-K}=K / 2$.

In the second case, each variable is included in any model with the same probability $\theta$. Consider a model $M_{\gamma}$ with $k_{\gamma}$ included explanatory variables. The prior probability of selecting this particular model is given by the binomial law: $p\left(M_{\gamma}\right)=\theta^{k_{\gamma}}(1-\theta)^{K-k_{\gamma}}$. Across all models, the expected model size is $K \theta$. The latter approach can be refined by defining specific values for the probability of including any particular variable. 
Let us now turn to parameters' priors, for which we use Zellner's $g$ prior. For a model $M_{\gamma}$, we need to specify prior distributions for parameters $\alpha_{\gamma}, \beta_{\gamma}$ and $\sigma$. For the constant and the variance of residuals, we use simple priors $p\left(\alpha_{\gamma}\right) \propto 1, p(\sigma) \propto \sigma^{-1}$. Moreover, we define the prior on the coefficients $\beta_{\gamma}$ as a normal distribution around a given mean and variance. The mean is commonly assumed to be 0 to reflect our ignorance on its sign. The covariance matrix is scaled on the data covariance matrix with $g$ a scale parameter:

$$
\beta_{\gamma} \sim N\left(0, \sigma^{2}\left(\frac{1}{g} X_{\gamma}^{\prime} X_{\gamma}\right)^{-1}\right)
$$

The parameter $g$ represents how certain we are a priori that the coefficients have zero mean, with a small $g$ meaning low variance and strong priors that the coefficients are zero.

The posterior distribution of the coefficients follows a t-distribution, with $E\left(\beta_{\gamma} \mid y, X, g, M_{\gamma}\right)=$ $\frac{g}{1+g} \beta_{\gamma}^{O L S}$, where $\beta_{\gamma}^{O L S}$ is the coefficient obtained from OLS regression. Hence the Bayesian coefficient is a linear combination of the prior (zero) and the OLS estimator, $g$ being the relative weight between the two.

The $g$ parameter can be chosen in various ways. A common benchmark is to use the unit information prior (UIP), setting $g=N$, and thus giving to the prior the weight of an observation. There are various alternatives such that $g=K^{2}$, which conforms to the risk inflation criterion (RIC) of George and Foster (1994), or $g=\ln (N)^{3}$, based on the Hannan-Quinn (HQ) criterion. There are unsettled discussions on the choice of the Zellner prior's main parameter, but the argument is that a large $g$ gives less weight to the prior and stay close to the OLS, while a smaller $g$ may not be robust to noises and risks of overfitting. In any case, we will use alternative priors to check the robustness of our results (see Liang and al. (2007) for further discussion on parameter priors).

\section{Model samplers}

With a large number of explanatory variables $K$, computing the marginal likelihood and the posterior distribution for each model is infeasible, as there are $2^{K}$ different models. ${ }^{3}$ But in most cases, the mass of the model posterior probability is concentrated on a small number of these models. Then the idea is to use the Metropolis-Hastings algorithm to "walk randomly" through the model space, making sure we visit its most important part.

The Metropolis-Hastings algorithm is built as follows. Assume that at step i the sampler has selected the model $M_{i}$ with $P M P_{i}=p\left(M_{i} \mid y, X\right)$. At step i+1, a model $M_{j}$ is drawn and replaces $M_{i}$ with probability $p_{i, j}=\min \left(1, \frac{P M P_{j}}{P M P_{i}}\right)$. After a large number of steps, the share of steps each model $\mathrm{i}$ is kept converges to its posterior model probability $P M P_{i}$.

3. In our main application, $\mathrm{K}=102$, so there are $5 \mathrm{e}^{30}$ possible models. 
At each step of the Metropolis-Hastings algorithm, there are two ways of choosing the proposed (but not necessarily selected) model for next step:

- The birth-death sampler randomly chooses one of the K variables, excludes it from the model $M_{i}$ if it is already included in it, or includes it otherwise.

- The reversible jump sampler implements the birth death sampler with a 50\% probability, or swaps two randomly selected variable inside and outside the model with probability $50 \%$. This sampler compares models of the same size half of the time.

The above algorithm needs a large number of iterations to converge. It is also important to drop a large number of the first iterations of the algorithm, or "burn-in iterations", so that the influence of the initial model is limited.

\section{The Determinants of Secondary School Outcomes in South Africa}

\subsection{BAM estimation of language test score determinants}

We apply the BMA framework to the whole set of possible explanatory variables. For lack of space, the detailed outcome of the BAM analysis is presented in Table 3 for the language test score only. However, the results are described in a standardized way for all test scores (language, maths and natural science) in Table 4.

Bayesian averaging techniques classify explanatory variables according to their robustness as measured by their posterior inclusion probability (henceforth PIP). In Table 3 we emphasize (in bold) the 31 explanatory variables with a PIP greater than 0.5 . Among those, 18 are contextual variables, 11 carry policy effects and two reflect the number of missing answers in questionnaires.

All robust contextual factors have the expected sign. For instance, individual characteristics such as gender, the frequent use of the language of test at home, parental wealth (dwelling equipment, electricity availability, meal frequency) and literacy, geographical dummies (Free State, Kwazulu Natal and Limpopo) as well as school socio-economic and historical background display robust coefficients. Note that the posterior mean effects of each variable (displayed on column 2) do not reflect magnitude, as explanatory variables have not been normalized (see below). 
Table 4. Bayesian Averaging Model Estimation of Language Test Scores

\begin{tabular}{|c|c|c|c|c|}
\hline & Variable & PIP & Post Mean & Post SD \\
\hline & \multicolumn{4}{|c|}{ dependent variable: square root of language score } \\
\hline \multicolumn{5}{|l|}{ Geographical characteristics } \\
\hline \multirow[t]{8}{*}{ Province } & Free State & 1.000 & 0.324 & 0.053 \\
\hline & Gauteng & 0.124 & 0.016 & 0.046 \\
\hline & Kwazulu Natal & 0.898 & -0.154 & 0.067 \\
\hline & Limpopo & 0.995 & -0.253 & 0.062 \\
\hline & Mpumalanga & 0.588 & 0.096 & 0.091 \\
\hline & North Cape & 0.100 & -0.012 & 0.039 \\
\hline & North West & 0.333 & 0.052 & 0.079 \\
\hline & Western Cape & 0.009 & 0.000 & 0.008 \\
\hline \multirow[t]{2}{*}{ Type of location } & Urban & 0.005 & 0.000 & 0.004 \\
\hline & Township & 0.011 & 0.000 & 0.005 \\
\hline Pupil characteristics & Female & 1.000 & 0.214 & 0.022 \\
\hline \multirow{3}{*}{ Population group } & Coloured & 0.153 & -0.018 & 0.046 \\
\hline & Indian & 0.012 & 0.002 & 0.026 \\
\hline & White & 0.011 & 0.001 & 0.010 \\
\hline \multirow[t]{2}{*}{ Language at home } & Afrikaan & 0.032 & -0.004 & 0.023 \\
\hline & English & 0.997 & 0.367 & 0.075 \\
\hline \multirow{4}{*}{ Family background } & Time to travel to school & 0.941 & -0.003 & 0.001 \\
\hline & Size of family & 0.922 & -0.019 & 0.008 \\
\hline & Learner lives with parents & 0.005 & 0.000 & 0.002 \\
\hline & Learner is orphan & 0.050 & -0.018 & 0.087 \\
\hline \multirow[t]{3}{*}{ Use of language of test at home } & Rarely & 0.999 & 0.222 & 0.047 \\
\hline & Sometimes & 1.000 & 0.331 & 0.034 \\
\hline & A lot & 1.000 & 0.642 & 0.053 \\
\hline \multirow[t]{7}{*}{ Home wealth } & Home has no electricity & 1.000 & -0.188 & 0.034 \\
\hline & Home equipment index & 1.000 & 0.037 & 0.007 \\
\hline & Meal frequency & 1.000 & 0.089 & 0.010 \\
\hline & Household literacy index & 1.000 & 0.073 & 0.009 \\
\hline & Parental involvement in education & 0.006 & 0.000 & 0.001 \\
\hline & Learner has skipped at least one class & 0.085 & 0.008 & 0.028 \\
\hline & Learner has repeated at least one class & 1.000 & -0.227 & 0.011 \\
\hline \multicolumn{5}{|l|}{ School characteristics } \\
\hline \multirow[t]{2}{*}{ School demography } & Gender ratio among teachers & 0.018 & 0.000 & 0.002 \\
\hline & School pupils-teacher ratio is over 25 & 0.020 & -0.001 & 0.008 \\
\hline \multirow{3}{*}{$\begin{array}{r}\text { School socio-economic background } \\
\text { School historic }\end{array}$} & Share of parents that pay fees & 0.011 & 0.000 & 0.000 \\
\hline & cal and socio-economic background index & 1.000 & 0.098 & 0.011 \\
\hline & School community involvement & 0.010 & 0.000 & 0.002 \\
\hline & School selection policy index & 0.896 & 0.045 & 0.019 \\
\hline \multirow[t]{5}{*}{ School wealth } & Use of LTSM funds & 0.006 & 0.000 & 0.000 \\
\hline & School infrastructure index & 0.007 & 0.000 & 0.001 \\
\hline & School has a computer laboratory & 0.999 & 0.172 & 0.035 \\
\hline & School has a science laboratory & 0.015 & 0.001 & 0.009 \\
\hline & School has a library & 0.997 & 0.148 & 0.031 \\
\hline \multirow[t]{4}{*}{ School Climate } & School climate & 0.508 & 0.009 & 0.010 \\
\hline & Learner misbehaviour & 0.129 & -0.002 & 0.006 \\
\hline & Learner absenteism & 0.018 & 0.001 & 0.005 \\
\hline & Teacher misconduct & 0.007 & 0.000 & 0.001 \\
\hline
\end{tabular}


Table 4 (continued)

\begin{tabular}{|c|c|c|c|c|}
\hline \multirow[t]{11}{*}{ Principal Characteristics } & Female & 0.011 & 0.000 & 0.005 \\
\hline & Qualification & 0.430 & 0.012 & 0.015 \\
\hline & Training & 0.195 & -0.006 & 0.012 \\
\hline & Total teaching experience & 0.066 & 0.000 & 0.002 \\
\hline & (square) & 0.940 & 0.000 & 0.000 \\
\hline & Working experience as a teacher & 0.014 & 0.000 & 0.000 \\
\hline & Has been trained in maths & 0.775 & 0.069 & 0.043 \\
\hline & Has been trained in language & 0.106 & 0.007 & 0.022 \\
\hline & Has been trained in science & 0.007 & 0.000 & 0.003 \\
\hline & Is teaching a class & 0.024 & -0.002 & 0.011 \\
\hline & Index of good practices & 0.014 & 0.000 & 0.002 \\
\hline \multirow[t]{7}{*}{ Educator Characteristics } & Female & 0.011 & 0.000 & 0.004 \\
\hline & Qualification & 0.998 & 0.049 & 0.010 \\
\hline & Training overall index & 0.924 & -0.017 & 0.007 \\
\hline & Training in ICT integration & 0.016 & 0.000 & 0.004 \\
\hline & Training at university & 0.009 & 0.000 & 0.002 \\
\hline & Total teaching experience & 0.975 & 0.007 & 0.002 \\
\hline & (square) & 0.035 & 0.000 & 0.000 \\
\hline \multicolumn{5}{|l|}{ Teaching policy } \\
\hline \multirow[t]{6}{*}{ Time table information } & Percentage of time allocated to teaching & 0.008 & 0.000 & 0.000 \\
\hline & Percentage of time allocated to teaching *subject ${ }^{*}$ & 0.036 & 0.003 & 0.020 \\
\hline & Index of other duties performed in school & 0.011 & 0.000 & 0.002 \\
\hline & Index of other duties performed outside school & 0.008 & 0.000 & 0.001 \\
\hline & Duration of a typical period (minutes) & 0.008 & 0.000 & 0.000 \\
\hline & High frequency of homework & 0.008 & 0.000 & 0.003 \\
\hline \multirow[t]{6}{*}{ Assessment policy } & Frequency of test & 1.000 & -0.177 & 0.010 \\
\hline & Type of test index & 0.010 & 0.000 & 0.001 \\
\hline & Use of multiple choice questions & 0.207 & -0.010 & 0.021 \\
\hline & All learners have portfolios & 0.006 & 0.000 & 0.002 \\
\hline & Some learners have portfolios & 0.006 & 0.000 & 0.002 \\
\hline & School has an assessment policy & 0.008 & 0.000 & 0.004 \\
\hline Curriculum policy & Teacher use curriculum directions & 0.014 & -0.001 & 0.007 \\
\hline Advancement in specific item & Speaking (low values) & 0.016 & 0.001 & 0.009 \\
\hline \multirow[t]{7}{*}{ of the curriculum } & Speaking (high values) & 0.468 & 0.008 & 0.010 \\
\hline & Reading (low values) & 0.701 & 0.072 & 0.054 \\
\hline & Reading (high values) & 0.202 & 0.003 & 0.007 \\
\hline & Writing (low values) & 0.007 & 0.000 & 0.005 \\
\hline & Writing (high values) & 0.010 & 0.000 & 0.001 \\
\hline & Reasoning (low values) & 0.006 & 0.000 & 0.007 \\
\hline & Reasoning (high values) & 0.012 & 0.000 & 0.001 \\
\hline \multirow[t]{2}{*}{ Use of school equipments } & Learner use the library & 0.365 & 0.044 & 0.062 \\
\hline & IT are used in class & 0.991 & 0.027 & 0.007 \\
\hline
\end{tabular}


$\mathrm{ECO} / \mathrm{WKP}(2013) 49$

Table 4 (continued)

Nb. missing values

$\begin{array}{rccc}\text { School equipment and use } & 0.007 & 0.000 & 0.000 \\ \text { School assessment policy } & 0.009 & 0.000 & 0.000 \\ \text { Principal competences } & 0.277 & -0.003 & 0.005 \\ \text { School climate } & 0.204 & 0.001 & 0.003 \\ \text { School selection policy } & 0.012 & 0.000 & 0.004 \\ \text { Curriculum issues } & 0.012 & 0.000 & 0.001 \\ \text { Household characteristics } & \mathbf{1 . 0 0 0} & -0.193 & 0.014 \\ \text { Pupil characteristics } & 0.097 & -0.011 & 0.038 \\ \text { School characteristics } & 1.000 & 0.045 & 0.007 \\ \text { School community involvement } & 0.016 & 0.001 & 0.009 \\ \text { School SES } & 0.008 & 0.000 & 0.001 \\ \text { Language assessment policy } & 0.009 & 0.000 & 0.000 \\ \text { Curriculum coverage } & 0.005 & 0.000 & 0.000 \\ \text { Class equipment } & 0.022 & 0.000 & 0.000 \\ \text { Class monitoring } & 0.013 & 0.000 & 0.001 \\ \text { Teaching intensity } & 0.023 & 0.000 & 0.001 \\ \text { Teacher qualification } & 0.190 & -0.001 & 0.003\end{array}$

\section{Statistics}

\begin{tabular}{rc} 
Mean nb. regressors & 33.48 \\
Draws & 2000000 \\
Burn-in & 20000 \\
Nb. models visited & 163408 \\
Nb. observations & 8832 \\
Model prior & random \\
g-prior & UIP \\
\hline
\end{tabular}

Let us now consider robust policy variables one by one. The first one, class repetition, displays a robust negative coefficient but it is hard to assess whether it reflects causality (as class repetition discourages pupils as argued by OECD, 2009) or unobserved heterogeneity (low cognitive capacities entailing both class repetition and low test scores). In case the latter correlation reflected causality, it would suggest that the extra years learners spend repeating a class do not help improve learning, and generate a waste of money and educational resources that could have been directed for instance towards remedial courses. Then, more selective schools have better results on average, but this result may be partly driven by the adverse selection of pupils.

School equipment in the form of having a computer laboratory and a library is a robust determinant of test scores. This is confirmed by the high PIP of the variables "IT used in class" (PIP of 0.99), and to a lesser extent, "Learner use the library" (PIP 0.36). We view this correlation as informative given that the analysis controls for a large number of school wealth and parental wealth variables. Hence robust correlations between test scores and school equipment are likely to reflect, in our view, a causal effect.

Turning to school principal and teacher characteristics, qualification and experience appear to be robust and positive determinants of test scores. The teacher training overall index displays a robust and negative sign, which may capture reverse causality (low-performing teachers being assigned extra training) or an unintended effect (training crowding out teaching time). Similarly, the negative coefficient of the 'test frequency' variable may either reflect reverse causality (low performance of schools triggering additional assessment) or unintended consequences like discouragement or a crowding out of teaching time. 
Finally, emphasis set on reading skills, and to a lesser extent, to speaking skills, is positively linked to language tests scores.

More than two thirds of explanatory variables are not robust, which is in line with the objective of selecting an optimal subset of robust determinants. It is worth noting that the type of neighborhood (city, township or rural) are not robust once socio-economic factors are accounted for, despite large differences in mean outcomes along the latter dimension.

\subsection{Assessing the magnitude of the effects}

On a second step, BAM estimates have been normalized for the three test scores: We calculate the predicted (relative) change in the dependent variable following an increase by one standard deviation in each explanatory variable, expressed as a percentage of the standard variation of the dependent variable.

The results are reported on Table 4. All effects that correspond to a PIP larger than 0.50 have been put in bold. Hence this Table allows to: i) check whether results pertaining to the language test score are also observed with other tests; ii) compare the magnitude of the effects at stake.

The results are reasonably consistent across the three sets of BAM regressions. Among contextual variables, the frequent use of the language of test, meal frequency, parental literacy and school socioeconomic background are always selected.

Among policy variables, we would like to emphasize that some meaningful correlations pertaining to school equipment and school climate are also quite robust. Indeed, the variable 'School has a library' has a PIP equal to $0.99,0.27$ and 0.59 in language, maths and science test scores respectively, while 'School climate' displays PIP values of 0.51, 1 and 0.94 respectively. Furthermore, PIP reach $0.99,1$ and 0.77 for the variable 'IT are used in class'. These policy variables can therefore be seen as important determinants of school outcomes.

Regarding the magnitude of the effects at stake, it is clear that contextual variables have the strongest impact. For instance, one standard deviation in the school socio-economic index represents between $12 \%$ and $17 \%$ of (square root) test scores' standard deviations. The largest estimate is similarly recorded in the language test score for those who speak the test language a lot at home (the correspondence between standard deviations is about $20 \%$ ). 
Table 5. Relative Impact of Covariates on Square Root of Test Scores

(in percent of dependent variable standard deviation)

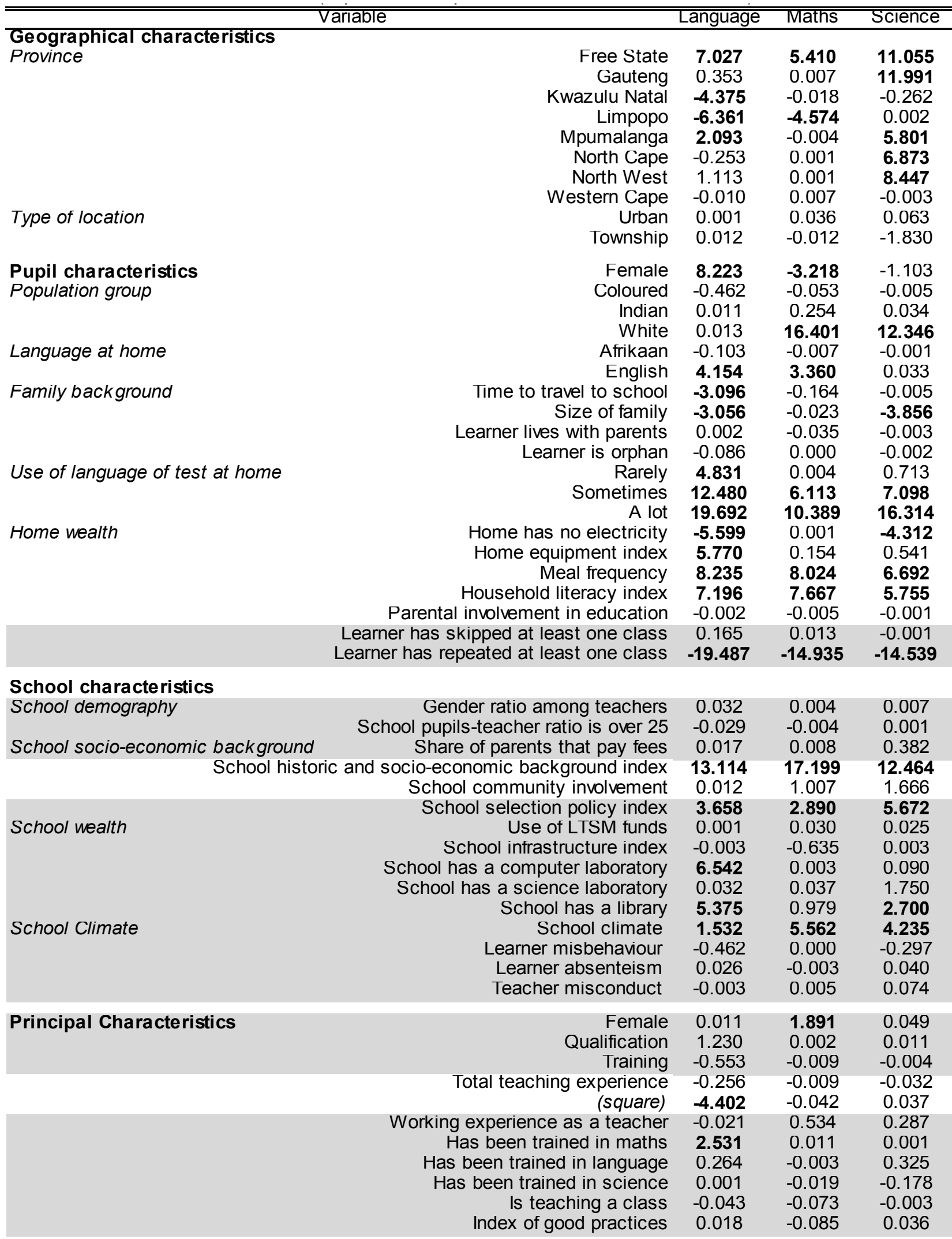


Table 5 (continued)

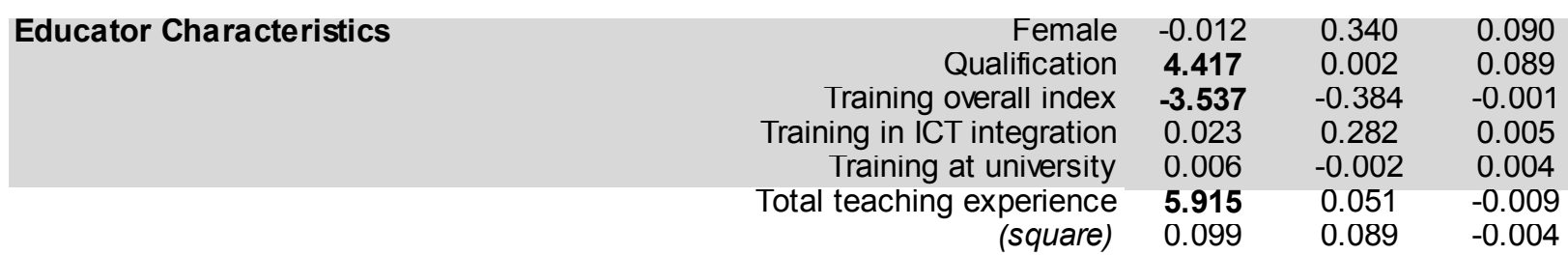

\begin{tabular}{|c|c|c|c|c|}
\hline Time table information & Percentage of time allocated to teaching & 0.006 & 1.712 & 0.007 \\
\hline & Percentage of time allocated to teaching ${ }^{*}$ subject $^{*}$ & 0.065 & -0.008 & 0.012 \\
\hline & Index of other duties performed in school & -0.014 & -0.019 & -1.029 \\
\hline & Index of other duties performed outside school & 0.000 & -0.008 & 0.000 \\
\hline & Duration of a typical period (minutes) & 0.006 & 0.003 & 0.009 \\
\hline & High frequency of homework & -0.005 & 0.006 & 0.004 \\
\hline Assessment policy & Frequency of test & -15.657 & -12.606 & -13.497 \\
\hline & Type of test index & -0.011 & -0.002 & 0.000 \\
\hline & Use of multiple choice questions & -0.502 & -0.010 & 0.037 \\
\hline & All learners have portfolios & 0.002 & 0.037 & -0.002 \\
\hline & Some learners have portfolios & -0.001 & -0.004 & -0.001 \\
\hline & School has an assessment policy & -0.009 & 0.003 & 0.016 \\
\hline Curriculum policy & Teacher use curriculum directions & -0.023 & 0.035 & 0.164 \\
\hline Advancement in specific item & item1 (low values) & 0.023 & 0.000 & -0.005 \\
\hline of the curriculum & item1 (high values) & 1.580 & 0.020 & 0.009 \\
\hline & item2 (low values) & 2.882 & -0.012 & 0.012 \\
\hline & item2 (high values) & 0.741 & 0.614 & 0.656 \\
\hline & item3 (low values) & 0.000 & 0.017 & -0.008 \\
\hline & item3 (high values) & 0.008 & 1.832 & 0.020 \\
\hline & item4 (low values) & 0.001 & 0.003 & \\
\hline & item4 (high values) & -0.015 & 3.850 & \\
\hline & item5 (low values) & & 0.004 & \\
\hline & item5 (high values) & & -0.591 & \\
\hline Use of school equipments & Learner use the library & 0.954 & 1.133 & 0.709 \\
\hline & $\mathrm{IT}$ are used in class & 4.697 & 7.651 & 3.558 \\
\hline Nb. missing values & & & & \\
\hline & School equipment and use & 0.003 & -0.673 & -0.499 \\
\hline & School assessment policy & -0.010 & -0.071 & -0.001 \\
\hline & Principal competences & -1.996 & -0.757 & -6.114 \\
\hline & School climate & 1.285 & 0.257 & 0.781 \\
\hline & School selection policy & 0.029 & -0.007 & 0.012 \\
\hline & Curriculum issues & 0.023 & 0.005 & -0.025 \\
\hline & Household characteristics & -14.811 & -12.460 & -13.757 \\
\hline & Pupil characteristics & -0.298 & -7.001 & -0.007 \\
\hline & School characteristics & 7.668 & 0.446 & -0.004 \\
\hline & School community involvement & 0.057 & -0.695 & -0.051 \\
\hline & School SES & -0.003 & 0.382 & 3.011 \\
\hline & Language assessment policy & 0.012 & 0.013 & 0.060 \\
\hline & Curriculum coverage & -0.002 & -0.087 & -0.082 \\
\hline & Class equipment & 0.060 & 0.018 & 0.036 \\
\hline & Class monitoring & 0.027 & 0.010 & 0.074 \\
\hline & Teaching intensity & 0.052 & -0.002 & 0.346 \\
\hline & Teacher qualification & -0.729 & 0.021 & -0.048 \\
\hline
\end{tabular}

Mean effect of 1 std. deviation increase of policy variable (as a \% of the std. deviation of the test score)

Note: Policy variables are shaded

This being said, the addition of our three meaningful policy variables ('School has a library', 'School climate' and 'IT are used in class') yields a sizeable effect: Adding one standard deviation in each of the above variables would increase the (square root) test score by $11-13 \%$. 


\section{Conclusion}

The analysis of tests scores at grade nine has confirmed the strong influence of largely inherited socio-economic factors in determining pupils' school outcomes. Yet, test scores determinants also include educational policy variables, which leave room for the South African government to improve the quality of education. In this paper we have considered about one hundred potential explanatory variables of test scores in order to minimize the risk of omitted variable bias. A Bayesian Averaging Model framework has allowed us to select the most robust ones. While contextual factors explain the bulk of the variance in test scores, we isolated four meaningful correlations between tests scores and respectively the availability of a library at school, the use of IT in the classroom, school climate and class repetition. Provided that these correlations reflect causality, a policy focus on improving school discipline and reducing absenteeism will have a positive impact on test scores. In addition, for students displaying low performance at school, class repetition without accompanying remedial programmes does not seem to be conducive to better learning outcomes. Finally, the availability of library and IT in the classroom is linked to improved performance. 


\section{References}

Ardington, C., Branson, N., Lam, D., Leibbrandt, M. (2011), "Explaining the Persistence of Racial Gaps in Schooling in South Africa", African Population Studies, vol.25:2, pp.509-542.

Armstrong, P. (2009), "The Impact of Teacher Characteristics on Student Performance: An Analysis using Hierarchical Linear Modelling”, Stellenbosch Economic Working Papers, No.07/09, Stellenbosch: South Africa.

Bhorat, H. and Oosthuizen, M. (2008), "Determinants of Grade 12 Pass Rates in the Post-Apartheid South African Schooling System", Journal of African Economies, vol.18:4, pp.634-666.

Case, A. and Deaton, A. (1999), "School Inputs and Educational Outcomes in South Africa", The Quarterly Journal of Economics, vol.114:3, pp.1047-1084.

Case, A. and Yogo, M. (1999), "Does School Quality Matter? Returns to Education and the Characteristics of Schools in South Africa", NBER Working Paper n.7399, National Bureau of Economic Research: Cambridge, Mass.

Chudgar, A. and Kanjee, A. (2009), "School Money: Funding the Flaws", HSRC Review, vol.7:4: pp.1819.

Fedderke, J.W. and Luiz, J.M (2002) "Production of Educational Output: Time-Series Evidence from Socioeconomically Heterogeneous Populations-the Case of South Africa, 1927-1993”, Economic Development and Cultural Change, vol.51:1, pp.161-187.

Fiske, E.B. and Ladd, H.F. (2003), "Balancing Public and Private Resources for Basic Education: School Fees in Post-Apartheid South Africa", Duke University, Terry Sanford Institute of Public Policy, Working Paper Series, SAN03-03.

Fleisch, B. (2008), "Primary education in crisis: Why South African schoolchildren underachieve in reading and mathematics", Juta: Cape Town.

Frempong, G., Reddy, V. and Kanjee, A. (2011), "Exploring Equity and Quality Education in South Africa using Multilevel Models", Compare: A Journal of Comparative and International Education, 41:6:819-835.

Gustafsson, M. (2007), "Using The Hierarchical Linear Model to Understand School Production in South Africa", working paper 01/07 of the Department of Economics and the Bureau for Economic Research at the University of Stellenbosch.

Gustafsson, M. and Mabogoane, T. (2010), "South Africa's Economics of Education: A stocktaking and an agenda for the way forward", working paper 06/10 of the Department of Economics and the Bureau for Economic Research at the University of Stellenbosch.

Hanushek, E.A. and L. Woessmann (2010), "The Economics of International Differences in Educational Achievement”, in Handbook of the Economics of Education, Volume 3. Eric A. Hanushek, Stephen J. Machin, Ludger Woessmann (Ed). Amsterdam: North Holland.

Hoeting, J. A., Madigan, D., Raftery, A. E. and Volinsky, C. T. (1999), "Bayesian Model Averaging: A Tutorial", Statistical Science, 14:4:382-417. 
Lam, D., Ardington, C. and Leibbrandt, M. (2008), "Schooling as a Lottery: Racial differences in school advancement in urban South Africa", University of Michigan, Population Studies Center Research Report, n.08-632.

Lee, V.E., Zuze, T.L. and Ross, K.N. (2005), "School Effectiveness in 14 Sub-Saharan African Countries: Links with $6^{\text {th }}$ graders' reading achievement", Studies in Educational Evaluation, vol.31 pp.207-246.

Liang, F., Paulo, R., Molina, G., Clyde, M. A., and Berger, J. O. (2008), "Mixtures of g Priors for Bayesian Variable Selection", Journal of the American Statistical Association, vol.103 pp.410:423.

Louw, M., Van der Berg, S. and Yu, D. (2007), Convergence of a Kind: Educational attainment and intergenerational social mobility in South Africa", South African Journal of Economics, 75:3:548571.

Moloi, M. and Strauss, J. (2005), "The SACMEQ II Project in South Africa: A study of the conditions of Schooling and the Quality of Education", SACMEQ: Harare.

OECD (2009), “PISA 2009 Results: What Makes a School Successful?” OECD Publishing, Paris.

OECD (2012), “Education at a Glance”, OECD Publishing, Paris.

Oosthuizen, M. and Bhorat, H. (2006), "Educational Outcomes in South Africa: A Production Function Approach", Development Policy Research Unit Working Paper funded by the Secretariat for Institutional Support for Economic Research in Africa, Cape Town: South Africa.

Reddy, V. (2006), "Mathematics and Science Achievement at South African Schools in TIMSS”, Cape Town: Human Sciences Research Council.

Reddy, V., Van der Berg, S., Janse van Rensburg, D. and Taylor, S. (2012), "Educational Outcomes: Pathways and performance in South African high schools", South African Journal of Science, 108:3:88-95

Taylor, S., Van der Berg, S., Reddy, V. and Janse van Rensburg, D. (2011), "How Well do South African Schools Convert Grade 8 Achievement into Matric Achievement?", working paper 13/11 of the Department of Economics and the Bureau for Economic Research at the University of Stellenbosch.

Taylor, S. and Yu, D (2009), "The importance of socio-economic in determining educational achievement in South Africa", working paper 01/09 of the Department of Economics and the Bureau for Economic Research at the University of Stellenbosch.

Van der Berg, S. (2007), “Apartheid's Enduring Legacy: Inequalities in Education”, Journal of African Economies, 16:5:849-880.

Van der Berg, S. (2008), "How effective are poor schools? Poverty and educational outcomes in South Africa", Studies in Educational Evaluation vol.34 pp.145-154.

Van der Berg, S. (2009), "The persistence of inequalities in education", Chapter 12 in: Janine Aron, Brian Kahn and Geeta Kingdon (eds), "South African Economic Policy under Democracy", Oxford University Press: Oxford: 327-354. 
Van der Berg, S. and Burger, R. (2003), "Education and Socio-Economic Differentials: A Study of School Performance in the Western Cape", Development Policy Research Unit Working Paper 03/73, Cape Town: South Africa.

Zeugner, S. (2011), "Bayesian Model Averaging with BMS", available at http://cran.rproject.org/web/packages/BMS/vignettes/bms.pdf. 
ECO/WKP(2013)49

\section{WORKING PAPERS}

The full series of Economics Department Working Papers can be consulted at www.oecd.org/eco/workingpapers/

1056. Improving education quality in South Africa

(June 2013) by Fabrice Murtin

1055. The 90\% public debt threshold: the rise and fall of a stylised fact

(June 2013) by Balázs Égert

1054. Challenges to sustain Poland's growth model

(June 2013) by Balázs Égert and Rafał Kierzenkowski

1053. Reforming agriculture and promoting Japan's integration in the world economy

(May 2013) by Randall S. Jones and Shingo Kimura

1052. Inequality and poverty in the United States: public policies for inclusive growth

(May 2013) by Oliver Denk, Robert Hagemann, Patrick Lenain and Valentin Somma

1051. Fiscal federalism and its impact on economic activity, public investment and the performance of educational systems

(May 2013) by Hansjörg Blöchliger, Balázs Égert and Kaja Fredriksen

1050. Restoring Japan's fiscal sustainability

(May 2013) by Randall S. Jones and Satoshi Urasawa

1049. Measuring total factor productivity at the firm level using OECD-ORBIS

(May 2013) by Peter Gal

1048. A projection method for public health and long-term care expenditures

by Christine de la Maisonneuve and Joaquim Oliveira Martins (forthcoming)

1047. R\&D, patenting and growth: the role of public policy

(May 2013) by Ben Westmore

1046. Knowledge-based capital, innovation and resource allocation

(May 2013) by Dan Andrews and Chiara Criscuolo

1045. Reforms for a Cleaner, Healthier Environment in China

(April 2013) by Sam Hill

1044. Making the tax system less distortive in Switzerland

(April 2013) by Andrés Fuentes

1043. The determinants of informality in Mexico's states

(April 2013) by Sean M. Dougherty and Octavio Escobar

1042. Legal reform, contract enforcement and firm size in Mexico

(April 2013) by Sean M. Dougherty 
1041. Improving the economic situation of young people in France

(April 2013) by Hervé Boulhol

Améliorer la situation économique des jeunes en France

(avril 2013) par Hervé Boulhol

1040. Improving employment prospects for young workers in Spain (April 2013) by Anita Wölfl

1039. Youth labour market performance in Spain and its determinants - a micro-level perspective (April 2013) by Juan J. Dolado, Marcel Jansen, Florentino Felgueroso, Andres Fuentes and Anita Wölfl

1038. The efficiency and equity of the tax and transfer system in France

(April 2013) by Balázs Égert

Efficacité et équité du système de prélèvements et de transferts en France

(avril 2013) par Balázs Égert

1037. Income inequality and poverty in Colombia. Part 2. The redistributive impact of taxes and transfers

(April 2013) by Isabelle Joumard and Juliana Londoño Vélez

1036. Income inequality and poverty in Colombia. Part 1. The role of the labour market (April 2013) by Isabelle Joumard and Juliana Londoño Vélez

1035. Policy options to durably resolve euro area imbalances

(March 2013) by Yvan Guillemette and Dave Turner

1034. Labour market, welfare reform and inequality in the United Kingdom

(March 2013) by Christophe André, Clara Garcia, Giulia Giupponi and Jon Kristian Pareliussen

1033. Work incentives and Universal Credit - reform of the benefit system in the United Kingdom (March 2013) by Jon Kristian Pareliussen

1032. Strengthening social cohesion in Luxembourg: making efficiency and equity go hand in hand (March 2013) by Jean-Marc Fournier and Clara Garcia

1031. The price of oil - Will it start rising again?

(March 2013) by Jean-Marc Fournier, Isabell Koske, Isabelle Wanner and Vera Zipperer

1030. The system of revenue sharing and fiscal transfers in China

(February 2013) by Xiao Wang and Richard Herd

1029. The declining competitiveness of French firms reflects a generalised supply-side problem (February 2013) by Hervé Boulhol and Patrizio Sicari

1028. Do the overall level and dispersion of socio-economic background measures explain France's gap in PISA scores?

(February 2013 by Hervé Boulhol and Patrizio Sicari

1027. Labour market performance by age groups: a focus on France

(February 2013) by Hervé Boulhol and Patrizio Sicari 